\title{
Clinical Reasoning: A 15-year-old boy with bilateral wrist pain in the setting of weight loss
}

K.H. Vincent Lau, MD, William S. David, MD, PhD, and Reza Sadjadi, MD

Neurology ${ }^{\circledR}$ 2019;92:486-492. doi:10.1212/WNL.0000000000007034
Correspondence

Dr. Sadjadi

rseyedsadjadi@

mgh.harvard.edu

\section{Section 1}

A 15-year-old previously healthy boy was referred for further evaluation of wrist pain. Right and left wrist pain started 2 years ago and got significantly worse in the setting of intentional 25pound weight loss over 6 months. He also had numbness in the 4th and 5th digits of his left hand for the last 3 months. Neurologic examination was notable for weakness of both thumb abduction, finger abduction, and flexion of 4th and 5th digits on the left. There was decreased sensation to pinprick in palms, as well as trace deep tendon reflexes at biceps, triceps, and brachioradialis.

\section{Questions for consideration:}

1. What is the localization of the patient's deficits?

2. What is the best next diagnostic step? 


\section{Section 2}

The patient's deficits localize to bilateral median nerves (thumb abduction) and bilateral ulnar nerves (finger abduction and flexion of left 4th and 5th digits). To better localize the neuropathies - for example, to determine if there is evidence of focal slowing at the carpal tunnel for the median nerves - the best next diagnostic step is nerve conduction studies (NCS). These were performed and are summarized in the table.

\section{Question for consideration:}

1. What is the interpretation of these NCS?

Table Nerve conduction studies

\begin{tabular}{|c|c|c|c|c|c|}
\hline \multirow{2}{*}{$\begin{array}{l}\text { Nerve/sites } \\
\text { Sensory }\end{array}$} & \multicolumn{2}{|l|}{ Distance, $\mathrm{cm}$} & Peak latency, ms & \multirow[t]{2}{*}{ Amplitude, $\mu \mathrm{V}$} & \multirow[t]{2}{*}{ Temp., ${ }^{\circ} \mathrm{C}$} \\
\hline & & & & & \\
\hline \multicolumn{6}{|c|}{ R median-Digit II } \\
\hline Digit II & 13 & & $4.4^{\mathrm{a}}$ & $7.4^{\mathrm{a}}$ & 29.4 \\
\hline Palm & 8 & & 3.2 & 46.3 & 29.3 \\
\hline \multicolumn{6}{|c|}{ L median-Digit II } \\
\hline Digit II & 13 & & $3.3^{\mathrm{a}}$ & 12.0 & 33.4 \\
\hline Palm & 8 & & 2.4 & 38.8 & 33.4 \\
\hline \multicolumn{6}{|c|}{ R ulnar-Digit V } \\
\hline Digit V & 11 & & 3.2 & 15.2 & 31.7 \\
\hline Palm & 8 & & 2.4 & 39.8 & 30.8 \\
\hline \multicolumn{6}{|c|}{ L ulnar-Digit V } \\
\hline Digit V & 11 & & 2.7 & 14.2 & 32.6 \\
\hline Palm & 8 & & 2.1 & 40.0 & 32.4 \\
\hline \multicolumn{6}{|c|}{$\mathrm{R}$ radial-snuff box } \\
\hline Forearm & 10 & & 2.9 & 32.8 & 28.3 \\
\hline \multicolumn{6}{|c|}{$L$ radial-snuff box } \\
\hline Forearm & 10 & & 2.4 & 35.7 & 32.7 \\
\hline \multicolumn{6}{|c|}{ R sural-lateral malleolus } \\
\hline Calf & 14 & & $4.8^{\mathrm{a}}$ & 19.7 & 30.8 \\
\hline \multicolumn{6}{|c|}{ L sural_- lateral malleolus } \\
\hline Calf & 14 & & $4.5^{\mathrm{a}}$ & 12.4 & 30.6 \\
\hline \multicolumn{6}{|c|}{ R superficial peroneal } \\
\hline Lateral leg & 14 & & 4.0 & 7.8 & 30.6 \\
\hline \multicolumn{6}{|c|}{ L superficial peroneal } \\
\hline Lateral leg & 14 & & 4.3 & 8.4 & 30.1 \\
\hline Nerve/sites & Distance, $\mathrm{cm}$ & Latency, ms & Amplitude, mV & Velocity, m/s & Temp., ${ }^{\circ} \mathrm{C}$ \\
\hline \multicolumn{6}{|l|}{ Motor } \\
\hline \multicolumn{6}{|c|}{$\mathrm{R}$ median-APB } \\
\hline Wrist & 6 & $5.7^{\mathrm{a}}$ & 13.5 & & 30.3 \\
\hline Elbow & 23.5 & 10.4 & 13.3 & 50.1 & 30.1 \\
\hline
\end{tabular}


Table Nerve conduction studies (continued)

\begin{tabular}{|c|c|c|c|c|c|}
\hline Nerve/sites & Distance, cm & Latency, ms & Amplitude, mV & Velocity, m/s & Temp., ${ }^{\circ} \mathrm{C}$ \\
\hline \multicolumn{6}{|l|}{ L median-APB } \\
\hline Wrist & 6 & $4.9^{a}$ & 9.8 & & 33.8 \\
\hline Elbow & 22.5 & 9.1 & 9.8 & 54.0 & 33.8 \\
\hline \multicolumn{6}{|l|}{ R ulnar-ADM } \\
\hline Wrist & 6 & 3.3 & 14.5 & & 28.4 \\
\hline B. elbow & 22 & 8.1 & 14.3 & 45.9 & 28.4 \\
\hline A. elbow & 10 & 11.4 & 13.4 & $30.0^{\mathrm{a}}$ & 28.3 \\
\hline \multicolumn{6}{|l|}{ L ulnar-ADM } \\
\hline Wrist & 6 & 2.4 & 11.0 & & 33.4 \\
\hline B. elbow & 21.5 & 6.5 & 10.9 & 52.3 & 33.5 \\
\hline A. elbow & 10 & 9.7 & 9.4 & $31.5^{a}$ & 33.8 \\
\hline \multicolumn{6}{|l|}{ R ulnar-FDI } \\
\hline Wrist & & 3.6 & 10.8 & & 32.4 \\
\hline B. elbow & 22 & 8.4 & 9.7 & 45.9 & 32.4 \\
\hline A. elbow & 10 & 11.7 & 8.0 & $30.5^{a}$ & 32.1 \\
\hline \multicolumn{6}{|l|}{ L ulnar-FDI } \\
\hline Wrist & & 3.8 & 9.2 & & 32.2 \\
\hline B. elbow & 21.5 & 7.8 & 9.2 & 52.9 & 32.4 \\
\hline A. elbow & 10 & 10.9 & 6.5 & $32.0^{a}$ & 32.9 \\
\hline \multicolumn{6}{|l|}{ R peroneal-EDB } \\
\hline Ankle & 9 & 5.6 & 8.4 & & 30.8 \\
\hline Below fibular head & 31 & 14.7 & 6.6 & $34.0^{a}$ & 31 \\
\hline Above fibular head & 9 & 16.7 & 6.3 & 46.7 & 30.8 \\
\hline \multicolumn{6}{|l|}{ L peroneal-EDB } \\
\hline Ankle & 9 & 5.9 & 7.9 & & 30.2 \\
\hline Below fibular head & 32 & 15.1 & 6.6 & $35.1^{a}$ & 30.2 \\
\hline Above fibular head & 9 & 17.0 & 6.2 & 45.5 & 30.4 \\
\hline \multicolumn{6}{|l|}{ R tibial-AH } \\
\hline Ankle & 10 & 6.0 & 11.2 & & 31.3 \\
\hline Popliteal fossa & 39.5 & 16.9 & 8.3 & $36.1^{a}$ & 31.1 \\
\hline \multicolumn{6}{|l|}{ L tibial-AH } \\
\hline Ankle & 10 & 5.4 & 8.0 & & 30.6 \\
\hline Popliteal fossa & 36 & 15.4 & 6.7 & $36.2^{\mathrm{a}}$ & 30.6 \\
\hline
\end{tabular}




\section{Section 3}

NCS demonstrated that bilateral median sensory nerve action potentials (SNAP) had prolonged distal latencies, with decreased amplitude on the right and normal amplitude on the left. Both median compound motor action potentials (CMAPs) had prolonged distal latencies, and bilateral ulnar CMAPs recording from the adductor digiti minimi and first dorsal interossei had focal slowing of conduction velocities across the elbows (i.e., ulnar grooves). Both sural SNAPs had prolonged peak latencies and bilateral peroneal and tibial CMAPs had slowed conduction velocities. Taken together, there was electrodiagnostic evidence for bilateral moderate median neuropathies at the wrist, i.e., carpal tunnel syndrome, and bilateral ulnar neuropathies localized to the elbows, superimposed on a generalized, demyelinating, sensorimotor polyneuropathy.

A month prior to the patient's referral visit, he had an ultrasound study of bilateral median and ulnar nerves (figure).

\section{Question for consideration:}

1. What is the interpretation of these ultrasound images?

Figure Ultrasound images of bilateral median and ulnar nerves

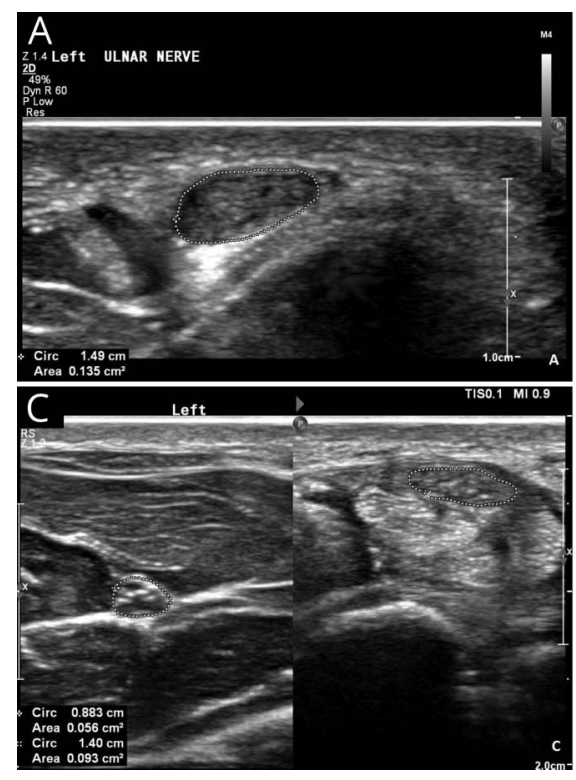

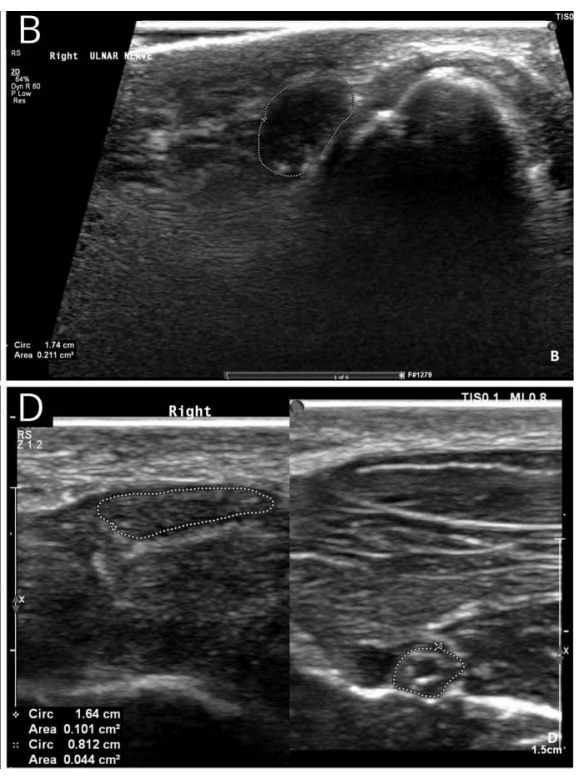

Ultrasound images demonstrate cross-sectional areas of (A) left ulnar nerve, (B) right ulnar nerve, (C) left median nerve at forearm (left) and wrist (right), and (D) right median nerve at wrist (left) and forearm (right).

GO TO SECTION 4 


\section{Section 4}

Ultrasound demonstrated abnormal ratios of wrist and midforearm cross-sectional areas (CSA) of bilateral median nerves (2.29 on right, 1.66 on left; normal $<1.4$ ) and increased CSA of bilateral ulnar nerves $\left(13.5 \mathrm{~mm}^{2}\right.$ on left, $21.1 \mathrm{~mm}^{2}$ on right; normal $<6.5 \mathrm{~mm}^{2}$ ). In nerve ultrasound, increased nerve CSA corresponds with swelling, which can be seen in any focal neuropathy; for example, the median nerve at the wrist in carpal tunnel syndrome. A nerve segment is considered abnormally large when its CSA is increased in absolute terms or relative to a distant, presumably normal segment. ${ }^{1}$ In this case, increased ratio of median nerve CSA at the wrists relative to the mid-forearms and increased absolute ulnar nerve CSA at the elbows suggest neuropathies localized to these compressible sites.

\section{Questions for consideration:}

1. What are the differential diagnoses for this patient's presentation?

2. What is the most likely diagnosis?

3. What test would confirm the diagnosis?

GO TO SECTION 5 


\section{Section 5}

The presentation of multiple focal mononeuropathies is suggestive of an underlying systemic process, as it would be highly unlikely for multiple neuropathies to occur coincidentally in an otherwise healthy individual. It is important to note that this presentation differs from that of the more common generalized polyneuropathy, for which nerve abnormalities are relatively uniform and not clearly localizable as in this case; this type of polyneuropathy can be seen in acquired disorders such as vitamin $B_{12}$ deficiency or inherited disorders such as CharcotMarie-Tooth (CMT) disease.

The differential diagnosis for multiple focal neuropathies is narrow compared to generalized polyneuropathy. In the general population, these include diabetes, connective tissue disorders such as systemic lupus erythematosus, and vasculitic disorders such as polyarteritis nodosa causing mononeuritis multiplex. Less common diagnoses include amyloidosis and leprosy. When multiple focal neuropathies are found at common compressive sites as in bilateral carpal tunnels and ulnar grooves as in this case, one specific diagnosis to consider is hereditary neuropathy with liability to pressure palsy (HNPP). This diagnosis is especially likely in a pediatric patient, in whom the aforementioned disorders associated with multiple focal neuropathies are much less likely compared to for an adult. While other systemic disorders can increase the risk of compressive neuropathy-for example, carpal tunnel syndrome in amyloidosis-multiple compressive neuropathies in different limbs and distributions is highly suggestive of HNPP, which is the most likely diagnosis in this case.

In our patient, targeted genetic testing for HNPP demonstrated heterozygosity for deletion of all 5 exons of the peripheral myelin protein-22 (PMP22) gene. He was diagnosed with HNPP with symptoms that were exacerbated by weight loss.

HNPP is a rare autosomal dominant peripheral neuropathy, with prevalence estimated between 0.84 and 16 per 100,000. Interestingly, a recent study in which next-generation sequencing-based copy number variation analysis was performed on asymptomatic newborns found a genetic prevalence characterized by PMP22 deletion of 58.9 per 100,000, which is unsurprising given the combination of underdiagnosis and likely incomplete penetrance of the disease. ${ }^{2}$ Age at onset of first HNPP symptoms is typically in the second or third decade, with range from birth to the eighth decade. Given the rarity of the disorder, the epidemiology of HNPP in children is not well-established, although it has been suggested that clinical suspicion should be high in children with multifocal neuropathy even without a family history (in the largest case series on pediatric HNPP to date, only $25 \%$ had affected family members). ${ }^{3}$

HNPP is characterized by recurrent peripheral nerve injury leading to weakness or sensory loss precipitated by minor compression or trauma. The weight loss noted in this case is a well-known risk factor for compression neuropathies in general, the mechanism thought to be multifactorial, including reduction of protective subcutaneous tissue and metabolic changes. ${ }^{4}$ The molecular basis of HNPP pathophysiology is related to interactions of the PMP22 protein with proteins that regulate myelin junctions. ${ }^{5}$

In HNPP, neurologic examination demonstrates weakness and sensory loss in the distribution of affected nerves, with diffusely reduced deep tendon reflexes in some cases. Electrophysiologic studies demonstrate decreased motor nerve conduction velocities, prolonged distal motor latencies predominantly at sites of common nerve entrapment, and abnormal sensory nerve action potentials even in clinically unaffected nerves. ${ }^{6}$ A recent study suggests that diagnostic workup for suspected HNPP should include a complete nerve conduction study with a minimum of bilateral median, ulnar, and peroneal nerves independent of symptomology, due to typical generalization of nerve involvement. ${ }^{7}$ Sonographic evaluation may be helpful in cases in which electrodiagnostic studies and genetic testing are unavailable or not completely consistent with $\mathrm{HNPP},{ }^{8}$ likely unnecessary in this case as electrodiagnostic studies were highly suggestive. In terms of genetics, a contiguous gene deletion of chromosome $17 \mathrm{p} 11.2$ including PMP22 is found in approximately $80 \%$ of affected patients. The remainder have a pathogenic variant in PMP22, the specific mutation of which can cause a continuum of severity, ranging from a minimally symptomatic presentation to one with persistent and progressive deficits approximating a CMT presentation. ${ }^{5}$

The management of HNPP is generally conservative, and patients are advised to avoid external compression and minor trauma. However, recent case reports have suggested benefit with steroids (demonstrated in one patient with improvement in motor function associated with radial nerve and another associated with peroneal nerve $)^{9}$ and IV immunoglobulins (demonstrated in one patient with improved lower extremity pain). ${ }^{10}$ These reports suggest that inflammation may be important in the pathophysiology of HNPP, especially in cases in which pain is a major symptom.

Our patient avoided compression at the wrists by using dictation software for school to limit typing time. He also participated in occupational therapy. Two months later, repeat examination demonstrated slight improvement in bilateral thumb abduction strength, and repeat NCS demonstrated slight improvement in amplitudes of bilateral median CMAPs and SNAPs. He was advised to maintain his current weight and to continue avoiding nerve compression.

\section{Author contributions}

Dr. Lau drafted the initial manuscript, revised the manuscript, and was involved in the clinical care of the patient. Dr. Sadjadi revised the manuscript and was involved in the clinical care of the patient. Dr. David was involved in the clinical care of the patient. 


\section{Study funding}

No targeted funding reported.

\section{Disclosure}

The authors report no disclosures relevant to the manuscript. Go to Neurology.org/N for full disclosures.

\section{References}

1. Suk JI, Walker FO, Cartwright MS. Ultrasonography of peripheral nerves. Curr Neurol Neurosci Rep 2013;13:328.

2. Park JE, Noh SJ, Oh M, Cho DY, Kim SY, Ki CS. Frequency of hereditary neuropathy with liability to pressure palsies (HNPP) due to $17 \mathrm{p} 11.2$ deletion in a Korean newborn population. Orphanet J Rare Dis 2018;13:40.

3. Chrestian N, McMillan H, Poulin C, Campbell C, Vajsar J. Hereditary neuropathy with liability to pressure palsies in childhood: case series and literature update. Neuromuscul Disord 2015;25:693-698.
4. Meylaerts L, Cardinaels E, Vandevenne J, et al. Peroneal neuropathy after weight loss a high-resolution ultrasonographic characterization of the common peroneal nerve. Skeletal Radiol 2011;40:1557-1562.

5. Taioli F, Cabrini I, Cavallaro T, Acler M, Fabrizi GM. Inherited demyelinating neuropathies with micromutations of peripheral myelin protein 22 gene. Brain 2011;134:608-617.

6. Verhagen WI, Gabreëls-Festen AA, van Wensen PJ, et al. Hereditary neuropathy with liability to pressure palsies: a clinical, electroneurophysiological and morphological study. J Neurol Sci 1993;116:176-184.

7. Robert-Varvat F, Jousserand G, Bouhour F, et al. Hereditary neuropathy with liability to pressure palsy in patients under 30 years old: neurophysiological data and proposed electrodiagnostic criteria. Muscle Nerve 2018;57:217-221.

8. Kim SH, Yang SN, Yoon JS, Park BJ. Sonographic evaluation of the peripheral nerves in hereditary neuropathy with liability to pressure palsies: a case report. Ann Rehabil Med 2014;38:109-115.

9. Heng HS, Tang SS, Goyal S, Wraige EA, Lim MJ. Beneficial use of steroids in hereditary neuropathy with liability to pressure palsy. Dev Med Child Neurol 2012;54:183-186.

10. Vrinten $\mathrm{C}, \mathrm{Gu} \mathrm{X}$, Weinreich SS, et al. An n-of-one RCT for intravenous immunoglobulin $\mathrm{G}$ for inflammation in hereditary neuropathy with liability to pressure palsy (HNPP). J Neurol Neurosurg Psychiatry 2016;87:790-791.

\section{Disputes \& Debates: Rapid online correspondence}

The editors encourage comments on recent articles through Disputes \& Debates:

Access an article at Neurology.org/N and click on "COMMENT" beneath the article header. Responses will be posted within 3 business days.

Before submitting a comment to Disputes \& Debates, remember the following:

- Disputes \& Debates is restricted to comments about studies published in Neurology within the last eight weeks

- Read previously posted comments; redundant comments will not be posted

- Your submission must be 200 words or less and have a maximum of five references; reference one must be the article on which you are commenting

- You can include a maximum of five authors (including yourself)

\section{Visit the Neurology ${ }^{\circledR}$ Resident \& Fellow Website}

Click on Residents \& Fellows tab at Neurology.org.

Now offering:

- Neurology ${ }^{\circledR}$ Resident \& Fellow Editorial team information

- "Search by subcategory" option

- E-pearl of the Week

- RSS Feeds

- Direct links to Continuum ${ }^{\circledR}$, Career Planning, and AAN Resident \& Fellow pages

- Recently published Resident \& Fellow articles

- Podcast descriptions

f Find Neurology ${ }^{\circledR}$ Residents \& Fellows Section on Facebook: http://tinyurl.com/o8ahsys

Follow Neurology ${ }^{\circledR}$ on Twitter: http://twitter.com/GreenJournal 


\section{Neurology}

\section{Clinical Reasoning: A 15-year-old boy with bilateral wrist pain in the setting of weight loss}

K.H. Vincent Lau, William S. David and Reza Sadjadi

Neurology 2019;92;486-492

DOI 10.1212/WNL.0000000000007034

This information is current as of March 4, 2019

\section{Updated Information \&} Services

References

Subspecialty Collections

Permissions \& Licensing

Reprints including high resolution figures, can be found at: http://n.neurology.org/content/92/10/486.full

This article cites 10 articles, 1 of which you can access for free at: http://n.neurology.org/content/92/10/486.full\#ref-list-1

This article, along with others on similar topics, appears in the following collection(s):

All Pediatric

http://n.neurology.org/cgi/collection/all_pediatric

EMG

http://n.neurology.org/cgi/collection/emg

Peripheral neuropathy

http://n.neurology.org/cgi/collection/peripheral_neuropathy

\section{Ultrasound}

http://n.neurology.org/cgi/collection/ultrasound

Information about reproducing this article in parts (figures,tables) or in its entirety can be found online at:

http://www.neurology.org/about/about_the_journal\#permissions

Information about ordering reprints can be found online:

http://n.neurology.org/subscribers/advertise

Neurology ${ }^{\circledR}$ is the official journal of the American Academy of Neurology. Published continuously since 1951, it is now a weekly with 48 issues per year. Copyright @ 2019 American Academy of Neurology. All rights reserved. Print ISSN: 0028-3878. Online ISSN: 1526-632X.

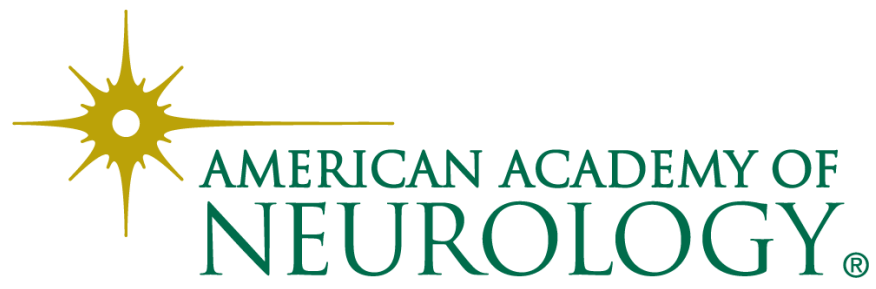

